\title{
IDENTIFIKASI BATAS SUB-CEKUNGAN HIDROKARBON MENGGUNAKAN ANALISIS SHD (SECOND HORIZONTAL DERIVATIVE) DAN SVD (SECOND VERTICAL DERIVATIVE) BERDASARKAN KORELASI DATA GAYABERAT DAN SEISMIK
}

\author{
Wuri Andari' ${ }^{1}$, Karyanto ${ }^{2}$, Riski Kurniawan ${ }^{3}$ \\ ${ }^{1,2}$ Teknik Geofisika, Universitas Lampung \\ Jurusan Teknik Geofisika, FT UNILA
}

${ }^{3}$ PT. Chevron Pasific Indonesia

\author{
Corresponding author: wuri.andari19@gmail.com \\ Manuscript received: June 16, 2018; revised: October 3, 2018; \\ Approved: December 5, 2018; available online: March 1, 2019
}

\begin{abstract}
Abstrak - Metode gayaberat secara umum dapat membaca perbedaan densitas batuan untuk mengidentifikasi struktur bawah permukaan. Penelitian ini dilakukan di daerah Riau dengan tujuan mengetahui struktur sesar, struktur bawah permukaan dengan pemodelan 2D dan menentukan batas sub-cekungan. Pengolahan data dilakukan dengan menggunakan analisis spektral, analisis SHD dan SVD serta pemodelan 2D yang dikorelasikan dengan penampang seismik untuk mengetahui struktur bawah permukaan daerah penelitian. Hasil penelitian menunjukkan nilai anomali bouguer daerah penelitian memiliki rentang nilai antara $5.6 \mathrm{mGal}$ hingga $33.2 \mathrm{mGal}$ dengan densitas rata-rata permukaan sebesar $1.95 \mathrm{gr} / \mathrm{cc}$. Anomali tinggi berada pada daerah bagian timur dan anomali rendah berada pada daerah berarah NW - SE. Banyaknya anomali rendah yang mengindikasikan pola sub-cekungan berjumlah 6 yang dipisahkan oleh daerahtinggian yang relatiftegasberarah Tenggara Baratlaut. Kedalaman rata-rata anomali residual berkisar $2.3 \mathrm{~km}$, berdasarkan hasil pemodelan 2Dbawahpermukaan terdapat struktur lapisan dari yang termuda yaitu endapan alluvial, Formasi Petanie, Kelompok Sihapas dan batuan granit sebagai batuan dasarnya. Penampang bawah permukaan yang diproyeksikan ke atas permukaan menunjukan adanya 5 sub-cekungan dengan lebar cekungan antara $4-12 \mathrm{~km}$ yang terletak di daerahindikasi sub-cekungan dan indikasi sesar daerah penelitian.
\end{abstract}

\begin{abstract}
Gravity method generally can read the difference of rock density to identify subsurface structures. This research was conducted in Riau area with the aim of knowing fault and subsurface structure, and determining sub-basin boundary. Data processing was done by using spectral analysis, SHD and SVD analysis, and $2 \mathrm{D}$ modeling then later correlated with seismic section to find out the subsurface structure of research area. The results showed that the bouguer anomaly value had a range of values between $5.6 \mathrm{mGal}$ to $33.2 \mathrm{mGal}$ with a surface density of $1.95 \mathrm{~g} / \mathrm{cc}$. High anomaly were in the eastern region and low anomaly were in the NW - SE trending region. 6 low anomalies indicated as a sub-basin pattern were separated by a relatively high altitude area of North West Southeast. The average residual anomaly depth was about $2.3 \mathrm{~km}$. Based on the 2D subsurface modeling results, there was layer structure from the youngest to eldest that were alluvial deposits, Petani Formation, Sihapas group and granitic rock as the base rock. The projected subsurface section to surface showed 5 sub-basins with basin width 4-12 km located in the sub-basin and fault indication area.
\end{abstract}

Keywords- Sub-Basin, SVD, SHD, Gravity, Seismic

How to cite this article:

Andari, W., Karyanto, dan Kurniawan, R. 2019. Identifikasi Batas Sub-Cekungan Hidrokarbon Menggunakan Analisis SHD (Second Horizontal Derivative) dan SVD (Second Vertical Derivative) Berdasarkan Korelasi Data Gayaberat dan Seismik. Jurnal Geofisika Eksplorasi, 5 (1) p.60-74. doi: 10.23960/ jge.v5i1.23 


\section{PENDAHULUAN}

Metode gayaberat merupakan salah satu metode yang ada dalam geofisika yang didasarkan pada variasi medan gravitasi akibat variasi rapat massa batuan di bawah permukaan sehingga dalam pelaksanaannya yang diselidiki adalah perbedaan medan gravitasi dari suatu titik observasi terhadap titik observasi lainnya (Sarkowi, 2008). Dengan melakukan penelitian menggunakan metode gayaberat diharapkan dapat mengetahui pola subcekungan, informasi batas cekungan, struktur dan pola tinggian (Basement High) serta struktur bawah permukaan suatu daerah ekplorasi.

Berdasarkan (Lawton dan Isaac, 2007) Penggabungan kedua metode antara Gayaberat dan Seismik pada penelitian stadi kasus Kanada menyatakan antara kesesuaian model seismik dan model gayaberat, metode gayaberat dalam hal eksplorasi dapat menentukan daerah salt, high velocity carbonater dan volcanic yang kurang dapat diintepretasi oleh seismik secara baik sehingga integrasi Gayaberat dan Seismik menghasilkan intepretasi geologi bawah permukaan yang optimal dibidang geometri struktur yang kompleks. Salah satu metode yang baik untuk mengkonfirmasi struktur bawah permukaan yaitu dengan menggabungkan anomali gayaberat dan section seismik yang terintegrasi untuk menentukan batas sub-cekungan sehingga pada eksplorasi lanjutan dapat terfokus pada daerah-daerah yang diindikasikan sebagai zona prospek saja.

Tujuan dari penelitian ini yaitu:

1. Mengidentifikasi zona patahan berdasarkan analisis SHD (Second Horizontal Derivative) dan SVD (Second Vertical Derivative).

2. Membuat model bawah permukaan menggunakan korelasi data anomali gayaberat dan seismik.
3. Menentukan litologi bawah
permukaan.

4. Menentukan batas cub-cekungan.

\section{TINJAUAN PUSTAKA}

\subsection{Fisiologi Daerah Penelitian}

Secara fisiografi, daerah penelitian berada pada Cekungan Sumatera Tengah.Cekungan Sumatera Tengah merupakan cekungan busur belakang yang berkembang di sepanjang tepi barat dan selatan Paparan Sunda terletak di Baratdaya Asia Tenggara. Cekungan sumatera tengah terletak diantara cekungan sumatera utara dan sekungan sumatera selatan. Cekungan sumatera tengah dibatasi oleh bukit barisan disebelah barat, di bagian timur dibatasi oleh semenanjung malaysia, dibagian baratlaut dibatasi oleh busur asahan dan dibagian tenggara dibatasi oleh tinggian tigapuluh.

\subsection{Struktur dan Tektonik Daerah Penelitian}

Cekungan Sumatera Tengah terbentuk akibat subduksi Lempeng Samudera Hindia yang menunjam ke bawah Lempeng Benua Eurasia pada awal Tersier (Eosen-Oligosen) dan merupakan seri dari struktur half graben yang terpisah oleh blok horst.Cekungan Sumatera Tengah juga mengalami gaya tektonik kompresi yang dihasilkan oleh suatu sistem sesar mendatar menganan akibat dari oblique subduction di bagian barat dan barat daya Sumatera(Yarmanto dan Aulia, 1988).Perkembangan tektonik pada cekungan sumatera tengah menjadi empat tahapan yaitu F0, F1, F2 dan F3.

\subsection{Stratigrafi Regional Daerah Penelitian}

Cekungan Sumatera Tengah dibagi menjadi empat unit stratigrafi. Urutan tersebut (dari tua-muda) menurut (Eubank 
dan Makki dalam Heidrick dan Aulia, 1993), yaitu:

1) Batuan Dasar (Basement)

Batuan dasar memiliki umur praTersier dan terbagi menjadi tiga satuan litologi yaitu: Mallaca Terrane, Mutus Assemblage, Kualu Terrane dan Mergui Terrane

2) Kelompok Pematang

Kelompok Pematang menumpang secara tidak selaras diatas batuan dasar. Sedimen-sedimen pada kelompok ini umumnya diendapkan pada lingkungan danau, sungai dan delta. William dan Kelley (1985) membagiKelompok Pematang menjadi lima formasi, yaitu: Formasi Lower Red Beds, Formasi Brown Shale, Formasi Coal Zone, Formasi Lake Fill, dan Formasi Fanglomerate.

3) Kelompok Sihapas

Kelompok Sihapas terdiri dari batupasir dengan sedikit selingan serpih, lapisan batugamping dijumpai secara lokal di bagian bawah. Kelompok Sihapas yang diendapkan secara tidak selaras di atas Kelompok Pematang terdiri dari Formasi Menggala, Bangko, Bekasap, Duri dan Telisa.

4) Kelompok Petani

Kelompok Petani terdiri dari Lower Petani yang merupakan endapan laut dan Upper Petani yang merupakan endapan laut sampai delta. Formasi Petani diendapkan mulai dari lingkungan laut dangkal, pantai dan ke atas sampai lingkungan delta yang menunjukkan regresi air laut. Formasi Petani terdiri dari batupasir, batulempung, dan batupasir gloukonitan dan batugamping yang dijumpai pada bagian bawah dari seri sedimen tersebut, sedangkan batubara banyak dijumpai pada bagian atas dan terjadi pada saat pengaruh laut semakin berkurang.

\subsection{Petroleum System Daerah Penelitian}

Batuan induk pada Cekungan Sumatera Tengah berasal dari Kelompok Pematang, reservoar terdapat pada Kelompok Sihapas yang berada tepat di atas batuan induk. Batuan tudung (seal/cap rock) dihasilkan oleh Formasi Telisa yang diendapkan di atas Kelompok Sihapas.Perangkap (trap) utama pada Cekungan Sumatera Tengah adalah perangkap struktur.

\section{TEORI DASAR}

\subsection{Metode Gayaberat}

Metode Gayaberat adalah metode dalam geofisika yang dilakukan untuk menyelidiki keadaan bawah permukaan berdasarkan perbedaan rapat massa cebakan mineral dari daerah sekeliling ( $\rho=$ gram $\left./ \mathrm{cm}^{3}\right)$. Metode ini disukai untuk mempelajari kontak intrusi, batuan dasar, struktur geologi, endapan sungai purba, lubang di dalam masa batuan, shaff terpendam dan lain-lain (Sarkowi, 2009).

\subsection{Konsep Dasar Gayaberat}

Teori yang mendukung Ilmu gravitasi terapan adalah hukum Newton (1687) yang menyatakan bahwa gaya tarik menarik antara dua partikel bergantung dari jarak dan massa masing-masing partikel tersebut, yang dinyatakan sebagaiberikut :

$\vec{F}(r)=-G \frac{m_{1} m_{2}}{r^{2}}$

Dimana

$F(r)$ : Gaya Tarik Menarik (N)

$m_{1}, m_{2}$ : Massa benda 1 dan massa benda 2 $(\mathrm{kg})$

$r \quad$ : Jarak antara dua buah benda (m)

$G$ :Konstanta Gravitasi Universal $(6,67 \mathrm{x}$ $10^{-11} \mathrm{~m}^{3} \mathrm{~kg} \mathrm{~s}^{-2}$ )

Newton juga mendefinisikan hubungan antara gaya dan percepatan. Hukum II Newton tentang gerak menyatakan gaya sebanding dengan perkalian massa benda 
dengan percepatan yang dialami benda tersebut.

$F=m \cdot g$

Percepatan sebuah benda bermassa $\mathrm{m}_{2}$ yang disebabkan oleh tarikan benda bermassa $M_{1}$ pada jarak $R$ secara sederhana dapat dinyatakan dengan:

$g=\frac{F}{m}$

\subsection{Koreksi Bouguer (Bouguer Corretion)}

Koreksi yang digunakan untuk menghilangkan perbedaan ketinggian dengan tidak mengabaikan massa di bawahnya sehingga harga gayaberat akibat massa di antara referensi antara bidang referensi muka air laut sampai titik pengukuran sehingga nilai g. Observasi bertambah. Adapun persamaan koreksi Bouguer:

$$
\begin{gathered}
B C=2 \pi . G . \rho . h \quad \mathrm{mGall} \\
B C=0.0419 \cdot \rho \cdot \square \mathrm{mGall}
\end{gathered}
$$

Dimana:

$\rho \quad$ : Massa jenis benda ( $\mathrm{g} / \mathrm{cc})$

$H$ : Elevasi terhadap mean sea level (m)

Kita substitusikan persamaan (1) dan persamaan (3) menjadi:

$g=\frac{F}{m}=G \frac{M \cdot m}{m \cdot r^{2}}=G \frac{M}{r^{2}}$

\subsection{Koreksi Medan (Terrain Correction)}

Adanya massa yang terletak di bawah permukaan antara titik pengamatan dan bidang spheroid pada ketinggian $h$ sangat mempengaruhi gaya gravitasi. Jika medan pengukuran relatif datar maka koreksi topografi/medan dapat diabaikan. Berikut penurunan koreksi medan adalah:

$$
g=\frac{0.425 x}{\pi} p\left\{\left(r_{2}-r_{1}\right)+\sqrt{r_{2}^{2}+L^{2}}-\sqrt{r_{2}^{2}+L^{2}}\right\}
$$

\subsection{Anomali Bouger}

Anomali Bouger merupakan perbedaan harga gravitasi bumi sebenarnya dengan harga gravitasi model bumi homogen teoritis di suatu datum referensi tertentu.

Anomali Bouguer dapat diukur dengan beberapa cara tergantung pada apakah kepadatan dan bentuk dataran antara titik pengukuran dan permukaan laut dihitung, diperkirakan, atau diabaikan. Rumus Anomali Bouguer:

$$
\Delta g=g_{o b s}-\left(g_{n}-K U B+K B-K M\right)
$$

\subsection{Analisis Spektral}

Analisis spektral untuk mengestimasi lebar jendela (Window Size) serta estimasi kedalaman anomali gayaberat. Analisi spektral dilakukan dengan cara mentransformasi Fourier lintasan yang telah ditentukan pada peta kontur Anomali Bouger Lengkap. Secara umum, suatu transformasi Fourier adalah menyusun kembali/mengurai suatu gelombang sembarang ke dalam gelombang sinus dengan frekuensi bervariasi dimana hasil penjumlahan gelombang-gelombang sinus tersebut adalah bentuk gelombang aslinya (Kadir, 2000).

Batas antara orde sattu (regional) dengan orde dua (residual), sehingga nilai $k$ pada batas tersebut digunakan sebagai penentu lebar jendela. Hubungan panjang gelombang $(\lambda)$ dengan komponen $k$ diperoleh dari persamaan (Blakely, 1996) : $k=\frac{a \pi}{\lambda}$

$k=(N-1) \Delta$

Dimana $\mathrm{N}=$ lebar jendela, maka didapatkan nilai estimasi lebar jendela.

\subsection{Filter Moving Average}

Moving Average dilakukan dengan cara merata-ratakan nilai anomalinya. Hasil dari perata-rataan ini merupakan anomali regionalnya. Sedangkan anomali residualnya didapatkan dengan mengurangkan data hasil pengukuran persamaan moving average untuk 1 dimensi adalah sebagai berikut:

$$
\Delta g_{r e g}(i)=\frac{\Delta g(i-n)+\cdots+\Delta g(i)+\cdots+\Delta g(i+n)}{N}
$$

Dimana $i$ adalah nomor stasiun. $N$ adalah lebar jendela, $\Delta g_{r e g}$ adalah besarnya anomali regional. Setelah didapatkan $\Delta T_{\text {reg }}$ , maka harga $\Delta T_{\text {residual dapat dihitung }}$ dengan menggunakan persamaan berikut :

$$
\Delta T_{\text {residual }}=\Delta T-\Delta T_{\text {reg }}
$$


Dimana:

$\Delta T_{\text {residual: }}$ Besarnya anomali residual.

\subsection{Second Horizontal Derivative (SHD)}

Metode ini dapat digunakan untuk menggambarkn struktur bawah permukaan yang dangkal maupun dalam. Amplitudo dari Horizontal Derivative ditunjukkan sebagai berikut (Cordell and Graunch, 1985):

$H G^{1 s t}=\sqrt{\left(\frac{\partial g}{\partial x}\right)^{2}+\left(\frac{\partial g}{\partial y}\right)^{2}}$

Dimana $\left(\frac{\partial g}{\partial x}\right.$ dan $\left.\frac{\partial g}{\partial y}\right)$ adalah turunan horisontal gayaberat pada arah $x$ dan $y$. Satuan dari $H G$ adalah $\mathrm{mGal} . \mathrm{m}^{-1}$. Dalam hal ini, persamaan yang dirumuskan oleh Cordell dan Graunch dimodifikasi sehingga didapatkan turunan kedua dari Horizontal Derivative seperti berikut

$H G^{2 n d}=\sqrt{\left(\frac{\partial^{2} g}{\partial x^{2}}\right)^{2}+\left(\frac{\partial^{2} g}{\partial y^{2}}\right)^{2}}$

Dimana untuk penurunan kearah $x, \frac{\partial^{2} g}{\partial y^{2}}$ dianggap nol, sebaliknya untuk penurunan kearah $y, \frac{\partial^{2} g}{\partial x^{2}}$ dianggap nol. Satuan dari penurunan kedua Horizontal Derivative adalah mGal.m ${ }^{-2}$.

\subsection{Second Vertical Derivative (SVD)}

Second Vertical Derivative (SVD) dilakukan untuk memunculkan efek dangkal dari pengaruh regionalnya dan untuk menentukan batas-batas struktur yang ada di daerah penelitian, metode ini diturunkan dari persamaan Laplace's (Telford dkk., 1976):nn,

$$
\begin{aligned}
\nabla^{2} \Delta g & =0 \\
\nabla^{2} \Delta g & =\frac{\partial^{2}(\Delta g)}{\partial x^{2}}+\frac{\partial^{2}(\Delta g)}{\partial y^{2}}+\frac{\partial^{2}(\Delta g)}{\partial z^{2}}
\end{aligned}
$$

Sehingga Persamaannya menjadi:

$$
\begin{gathered}
\frac{\partial^{2}(\Delta g)}{\partial x^{2}}+\frac{\partial^{2}(\Delta g)}{\partial y^{2}}+\frac{\partial^{2}(\Delta g)}{\partial z^{2}}=0 \\
\frac{\partial^{2}(\Delta g)}{\partial z^{2}}=-\frac{\partial^{2}(\Delta g)}{\partial x^{2}}+\frac{\partial^{2}(\Delta g)}{\partial y^{2}}
\end{gathered}
$$

Filter second Vertical Derivative (SVD) dengan operator Elkins filter 2-D ditunjukkan pada tabel berikut:

\subsection{Forward Modeling (Pemodelan ke Depan) \\ Forward modeling (pemodelan ke de-} pan) adalah suatu metode interpretasi yang memperkirakan densitas bawah permukaan dengan membuat terlebih dahulu benda geologi bawah permukaan. Kalkulasi anomali dari model yang dibuat kemudian dibandingkan dengan anomali Bouger yang telah diperoleh dari survey gayaberat. Prinsip umum pemodelan ini adalah meminimumkan selisih anomali pengamatan untuk mengurangi ambiguitas.

\subsection{Gelombang Seismik}

Dalam menentukan litologi batuan dan struktur geologi, metode seismik aktif dikategorikan menjadi dua bagian yaitu metode seismik refleksi dan seismik refraksi. Metode seismik refleksi biasanya digunakan untuk menentukan litologi batuan dan struktur geologi pada kedalaman yang dalam sedangkan metode seismik refraksi digunakan untuk menentukan litologi dan struktur geologi yang relatif dangkal.

\subsection{Hubungan Kecepatan dan Densitas Batuan}

Formasi Besarnya cepat rambat gelombang $\mathrm{P}$ dalam lapisan batuan dipengaruhi oleh elastisitas dan densitas batuan. Sehingga dengan mengetahui cepat rambat gelombang $\mathrm{P}$ pada lapisan batuan maka akan diketahui tingkat kekerasan lapisan atau densitas batuan tersebut. Dalam penentuan densitas batuan digunakan rumus empiris yang diambil dari Gardner's relationship, dengan menggunakan kecepatan gelombang $\mathrm{P}$ untuk memprediksikan densitas suatu batuan. Gardner et. al. melakukan serangkaian studi empiris dan menemukan 
hubungan antara kecepatan dan densitas sebagai berikut:

$\rho=\alpha V^{\frac{1}{4}}$

Dimana:

$\rho$ : Densitas batuan, dalam $\mathrm{gr} / \mathrm{cm}^{3}$

$\alpha \quad: 0.31$ (Konstanta Gardner)

$V$ : Kecepatan gelombang $\mathrm{P}$, dalam $\mathrm{m} / \mathrm{s}$

(Nurdiyanto dkk, 2011).

\section{METODE PENELITIAN}

\subsection{Lokasi dan Waktu Penelitian}

Penelitian dilakukan di PT. Chevron Pasific Indonesia Rumbai, Pekanbaru Provinsi Riau. Penelitian dilakukan pada tanggal 25 April hingga 16 Juni 2017 dengan judul Pemantauan Proses Injeksi Air pada Lapangan "SMR" Cekungan Sumatera Tengah Berdasarkan Data Anomali Time-lapse Microgravity.

\subsection{Alat dan Bahan Penelitian}

1. Laptop, data gayaberat dan Section Seismik (*PNG)

2. Softfile peta geologi dan Shuttle Radar Topography Mission

3. Software ArcGis V 10.1

4. Software Geosoft Oasis Montaj V 8.4

5. Software Global Mapper V 17

6. Software Microsoft Excel

\subsection{Prosedur Penelitian}

Dalam penelitian ini, prosedur untuk melaksanakan penelitian dibagi menjadi 3 bagian yaitu:

\section{Prosedur Pengolahan data}

Data gayaberat pada pengolahan ini bukan merupakan data observasi pengukuran lapangan melainkan data citra satelit yang diperoleh dalam bentuk FAA. Sehingga dalam pengolahannya perlu dilakukan koreksi untuk mendapatkan nilai anomali bouguer lengkap (CBA) dimana dalam perhitungannya dilakukan dengan menggunakan software Geosoft 8.3.3.

\section{Analisis Spektral}

Dalam tahap analisis dilakukan analisis Transformasi Fourier menggunakan data Complete Bouger Anomali untuk merubah domain data dari spasial jarak ke spasial frekuensi. Hasil dari proses FFT adalah nilai real dan imajiner dari setiap lintasan yang selanjutnya akan diproses dengan menggunakan perangkat lunak Ms. Excel untuk mendapatkan nilai amplitudo (A), ln A, frekuensi dan nilai bilangan gelombang k. Nilai amplitudo (A) dihasilkan dengan cara menghitung akar kuadrat dari nilai real dan imajiner. Nilai $\ln$ A dihasilkan dengan cara melogaritmakan nilai amplitude (A). Perhitungan nilai frekuensi bergantumg pada domain spasial yang telah ditentukan sebelumnya. Dimana dengan mengetahui besarnya nilai $k$. Setelah nilai terhitung maka dilakukan ploting pada nilai $k$ dan nilai $\operatorname{Ln} A$. sehingga akan diperoleh nilai cut off pada daerah tersebut yang akan digunakan pada penentuan besarnya lebar jendela. Sedangkan nilai regresi linier pada zona residual akan digunakan untuk pemodelan bawah permukaannya.

\section{Pemodelan Indikasi Struktur Sesar}

Perkiraan ataupun indikasi sesar dilakukan dengan menggunakan analisis SHD dan SVD, sesuai dengan informasi regional daerah penelitian analisis secara horizontal dilakukan menggunakan 2 sudut yaitu EW untuk mengetahui keberadaan patahan berarah NS dan sw ne untuk mengetahui keberadaaan patahan berarah NW SE. Indikasi patahan menggunakan analisis SVD dilakukan dengan menggunakan perumusan matrik ordo 5 x 5 yakni matrik elkins, dengan indikasi keberadaan sesarnya yang semestinya meyerupai analisis SHD. Dari kedua analisis tersebut kemudian dilakukan overly untuk mengetahui daerah yang tegas menyatakan adanya suatu 
patahan secara lateral horizontal dari atas permukaan.

\section{Pemodelan Bawah Permukaan}

Pemodelan kedepan 2D (Forward Modeling) yang dibuat berdasarkan data resdiual. Forward modeling dilakukan dengan menggunakan software Geosoft dengan cara menginput data grid residual yang telah diperoleh kemudian menarik garis atau membuat slice pada daerah yang terindikasi cekungan yaitu melewati daerah dengan anomali tinggi dan rendah menarik lintasan dengan melewati setiap deposenter dan tinggian sub cekungan yang telah ditentukan pada proses sebelumnya. Slice yang dilakukan didasarkan pada keterdapatan lintasan seismik pada daerah penelitian yang selanjutnya pada pemodelan akan dikorelasikan antara grafik anomali gayaberat dengan penampang bawah permukaan dari seismik dengan melakukan picking seperti perlapisan yang ada pada seismik dengan input nilai densitas dan velocity yang diperoleh dari data checkshot.

\section{HASIL DAN PEMBAHASAN}

\subsection{Anomali Bouguer}

Pada penelitian ini penulis menggunakan data sitra satelite yaitu data yang diperoleh telah terkoreksi hingga mendapatkan hasil download data berupa nilai FAA dalam format * grd seperi pada Gambar 2 dimana nilai anomalinya berada antara $5.75 \mathrm{mGal}$ hingga 29.46 mGal. Dari data FAA penulis melakukan reduksi dengan grid peta topografi menggunakan software Geosoft dengan menu Gayaberat.omn yang sebelumnya diperoleh nilai densitas rata-rata permukaan daerah penelitian sebesar 1.95 gr/cc. Nilai anomali bouguer lengkap yang diperoleh pada penelitian ini memiliki rentang nilai antara $5.6 \mathrm{mGal}$ hingga 33.2
mGal. Hasil tersebut merupakan respon dari variasi rapat massa batuan yang ada pada daerah penelitian.

Dalam hal ini rentang nilai anomali dibedakan menjadi 3 bagian yaitu anomali rendah, anomali sedang dan anomali tinggi. Anomali rendah ditunjukan daerah dengan interval warna antara warna bitu tua sampai biru muda dengan rentang nilai anomali antara $5.6 \mathrm{mGal}$ sampai 10.6 mGal dengan arah relative Utara - Selatan, warna hijau sampai pada warna kuning menunjukkan anomali sedang dengan rentang nilai anomali antara $10.6 \mathrm{mGal}$ sampai $14.8 \mathrm{mGal}$ tersebar dengan arah Utara - Selatan dan Baratlaut - Tenggara, sedangkan untuk anomali tinggi berada antara warna kuning muda hingga merah muda dengan rentang nilai antara 14.8 mGal hingga $33.2 \mathrm{mGal}$ sengan arah cenderung Utara - Selatan pada bagian Timur daerah penelitian dan cendering berarah Baratlaut - Tenggara pada bagian Baratdaya daerah penelitian. Secara keseluruhan peta anomaly bouguer lengkap tersebut memperlihatkan pola struktur graben yang menunjukan kearah Baratlaut - Tenggara dan Utara - Selatan.

\subsection{Analisis Spektral}

Analisis spektral ini dilakukan untuk memisahkan antara anomali dangkal yaitu daerah dengan nilai frekuensi tinggi dan amplitudo rendah dengan anomali dalam yang memiliki niali frekuensi rendah serta amplitudo yang relative tinggi dengan melakukan Transformasi Fourier dari data anomali bougeur untuk mengubah data Gayaberat yang berdomain spasial, menjadi data Gayaberat yang berdomain frekuensi. sebesar $1000 m$ untuk mengetahui

Untuk menghitung nilai cut off dan penentuan lebar jendela yang akan digunakan penulis membuat 5 lintasan FFT dimana pada ke 6 lintasan tersebut melewati anomali dengan nilai anomali rendah hingga anomali dengan nilai yang tinggi. Berdasarkan analisis dari kelima 
grafik spektral diatas, didapatkan lebar jendela yang digunakan dalam penentuan lebar jendela moving average untuk memisahkan antara respon regional (respon Gayaberat dalam) dan respon residual (respon Gayaberat dangkal) seperti yang terlihat pada Tabel 2 di bawah ini

Berdasarkan tabel tersebut di bawah dapat diketahui bahwa rata rata kedalaman anomali dalam yaitu sekitar $13050 \mathrm{~m}$ dan rata-rata kedalaman anomali dangkalnya mencapai $2265 \mathrm{~m}$ sedangkan lebar jendela yang digunakan adalah 23 x 23 dengan Grid Cell Size adalah 1000 m.

\subsection{Anomali Regional}

Kontur yang diperoleh menunjukan hasil yang relative sama dengan kontur anomali bouguernya dengan rentang nilai antara $5.5 \mathrm{mGal}$ sampai $33.2 \mathrm{mGal}$ seperti pada Gambar 3. Rata-rata kedalaman regional mencapai $13050 \mathrm{~m}$, hal ini mengasumsikan bahwa pada kedalaman yang lebih dalam menunjukan jenis batuan yang homogen sedangkan pada kedalaman yang lebih rendah dari $13050 \mathrm{~m}$ merupakan jenis batuan sedimen ataupun batuan permukaan yang cukup bervariasi.

\subsection{Anomali Residual}

Biasanya jenis batuan yang mengisi anomali ini adalah batuan sedimen yaitu batuan yang memiliki nilai densitas relative rendah. kontur anomali dangkal memiliki niali berkisar $-2.1 \mathrm{mGal}$ hingga $2.4 \mathrm{mGal}$. Jika dibandingkan dengan nilai anomali yang ada pada anomali residual nilai ini terpaut cukup jauh dimana pada regional rentang nilai anomali yang sama dengan anomali bouguernya berkisar antara $5.5 \mathrm{mGal}$ hingga $33.2 \mathrm{mGal}$ seperti pada Gambar 4. Estimasi kedalaman yang diperoleh sari analisis spectral menyatakan anomali residual ini memiliki kedalaman estimasa rata-rata mencapai $2265 \mathrm{~m}$.

Terdapat 6 indikasi sub-cekungan yang ada pada daerah penelitian yaitu subcekungan A, sub-cekungan B, sub- cekungan $\mathrm{C}$, sub-cekungan $\mathrm{D}$, subcekungan $\mathrm{E}$ dan sub-cekungan $\mathrm{F}$, yang ditandai dengan adanya deliniasi pada pola anomali residual tersebut. Pola yang terlihat cenderung mengikuti kontur yang ada yaitu antara kontur tinggian dan kontur dengan nilai anomali rendah yang cenderung tegas mengarah ke tenggara baratlaut yang ditunjukan pada Gambar 4.

\subsection{Second Horizontal Derivative (SHD)}

Berdasarkan persamaan SHD turunan pertama dan kedua kearah $x\left(\mathrm{~N} 315^{\circ}\right)$ yang bertujuan mendapatkan sesar yang relatif berarah NE-SW. Sebaliknya turunan pertama dan kedua yang berarah $y\left(\mathrm{~N}^{\circ} 5^{\circ}\right)$ bertujuan mendapatkan sesar yang relatif berarah NW-SE. Dari hasil analisis SHD baik pada penurunan arah $\mathrm{N} 45^{\mathrm{O}}$ maupun $\mathrm{N} 315^{\circ}$ yang telah dilakukan sebelumnya diperoleh sesar-sesar yang memanjang kearah North East to South West dan North West to South East Berdasarkan gambar diatas terdapat 15 sesar yang mengarah ke North East to South West dan 22 sesar mengarah ke North West to South East. Untuk melihat keselarasan antara sesar berdasarkan analisis SHD dilakukan dengan mengorelaikan indikasi tersebut dengan analisis SVD (Second Vertical Derivative).

\subsection{Second Vertical Derivative (SVD)}

Analisis SVD silakukan menggunakan program filter 5x5 symmetric convolution dengan filter yang digunakan yitu elkins, filter elkins banyak digunakan dalam penentuan jenis sesar daerah penelitian yaitu mementukan jenis sesar naik, sesar normal ataupun sesar mendatar. Sebaran sesar berdasarkan analisis SVD terdapat indikasi patahan berjumlah 33 sesar, dan dapat dilihat bahwa arah patahan cenderung berarah SE-NW, meski demikian terdapat beberapa sesar yang menunjukkan arah lainnya.

Dari korelasi antar keduanya terdapat banyak kesesuaian antara SVD dan SHD yang menyatakan kedunya mengidentifikasi 
letak dan arah sesar yang secara keseluruhan atau sebagian besar adalah sama. Sehingga dapat diyakini pada daerah penelitian terdapat sesar beraahseperti pada peta. Pada gambar diatas terlihat terdapat sebanyak 23 patahan yang terkorelasi secara baik dari analisis SVD maupun SHD. Pada Gambar 5 korelasi antara SHD dan SVD merupakan daerah yang diyakini terdapat suatu sesar yang benar.

Patahan-patahan yang muncul dilakukan korelasi dengan penampang anomaly residual yang menunjukkan letak sesar cenderung mengelilingi ataupun membatasi daerah diposenter yang diindikasikan sebagai daerah sub cekungan. Sedangkan untuk penentuan jenis patahan dapat diketahui melalui analisis forward modeling.

\subsection{Forward Modelling}

Untuk mendapatkan pola cekungan yang ada pada daerah penelitian penulis membaginya dalam 4 lintasan yang juga dilalui oleh pengkuran seismik. Dalam penentuannya penulis menggunakan nilai velocity yang diperoleh atau diketahui dari data seismik yang ada, Penampang bawah permukaan seismik yang dalam hal ini tertera dalam domain waktu (PSTM). Hasil 2d bawah permukaan terdapat pada lampiran Gambar 6 sebagai salah satu hasil model 2D yang mewakili 4 lintasan lainnya Terlihat urutan stratigrafi dari yang paling muda adalah batuan aluvial disusul oleh formasi petani, sihapas grup kemudian basement dengan litologi batuan granit. Pada lintasan S1-S1' terdpat dua sub-cekungan, kemudian untuk setiap lintasan lainnya masing-masing memiliki satu buah sub cekungan yang terprtakkan oleh model 2D. Setiap lintasan yang diambil sebagai contoh bahan penelitian memilii setidaknya 1 cekungan yang ratarata kedalaman cekungan tersebut mencapai $2.3 \mathrm{~km}$ dari permukaan dengan lebar cekungan antara $4 \mathrm{~km}$ hingga 12 $\mathrm{km}$. Korelasi yang dihasilkan dari keseluruhan analisis yang telah dilakukan menghasilkan peta batas sub cekungan seperti pada Gambar 7 , dimana titik batas sub cekungan yang diperoleh pada analisis forward modeling berada pada garis sesar yang diindikasikan pada analisis SHD dan SVD serta berada pada darah indikasi pola sub-cekungannya daerah anomali residual.

\section{KESIMPULAN DAN SARAN}

\subsection{Kesimpulan}

Adapun kesimpulan dalam penelitian ini adalah sebagai berikut:

1. Daerah penelitian memiliki nilai anomali bouguer sebesar $5.6 \mathrm{mGal}$ hingga $33.2 \mathrm{mGal}$ dan densitas rata-rata permukaan $1.95 \mathrm{gr} / \mathrm{cc}$ serta memiliki daerah dengan anomaly tinggi berada pada daerah Barat dan anomaly rendah berada pada tengah daerah peneliian yang berarah Tenggara - Baratlaut.

2. Prediksi kedalaman sedimen berdasarkan hasil analisis spectral yaitu 2.4 $\mathrm{Km}$ dibawah permukaan yang terkonformasi oleh analisis forward modeling.

3. Lokalisasi sesar berdasarkan analisis SHD dan SVD menghasilkan arah sesar tegas kearah NW - SE yang selaras dengan informasi geologi regional daerah penelitian.

4. Secara umum daerah penelitian terdapat 6 sub-cekungan dengan pola tinggian (basement high) yang memisahkan subcekungan satu dengan sub-cekungan lainnya sedangkan itik batas sub-cekungan berada pada lingkup daerah deliniasi yang diindikasikan sebagai sub-cekungan dan berada pada garis indikasi sesar.

5. Pemodelan kedepan (forward modeling) dengan data pendukung seismicsection menghasilkan model bawah permukaan yang sama seperti perlapisan yang ada pada model seismik daerah penelitian dengan litologi daerah penelitian dari permukaan ke basement dimulai dari batuan alluvial $(1.9 \mathrm{gr} / \mathrm{cc})$ disusul oleh 
formasi petani $(2.3 \mathrm{gr} / \mathrm{cc})$, sihapas grup (2.45 gr/cc) kemudian basement yang berupa litologi batu granit $(2.6 \mathrm{gr} / \mathrm{cc})$ yang berkorelasi dengan informasi geologi daerah penelitian.

\subsection{Saran}

Adapun saran yang dapat diberikan yaitu agar studi penelitian dilakukan dengan menggunakan data pengukuran lapangan secara langsung baik pengukuran gayaberat maupun pengukuran seismik serta informasi geologi yang menunjang agar hasil yang diperoleh lebih akurat.

\section{DAFTAR PUSTAKA}

Blakley, RJ., 1996. Potential Theory in Gayaberat and Magnetic Applications, Cambridge University Press, Cambridge

Cordell, L., and Grauch, V. J. S., 1985. Mapping Basement Magnetization Zones From Aeromagnetic Data in The San Juan Basin, New Mexico, in Hinze, W. J., Ed., The Utility of Regional Gayaberat and Magnetic Anomaly Maps: Sot. Explor. Geophys., 181 and 197

Elkins, T.A., 1951. The Second Derivative Methode of Gravity Interpretation Geophysics. Bab XVI. Hal 29-50 dan V.23, 97-127.

Kadir, W.G.A., 2000. Diktat Kuliah: Eksplorasi Gayaberat dan Magnetik. Jurusan Teknik Geofisika Fakultas Ilmu Kebumian dan Teknologi ineral, ITB. Bandung

Lawton, D.C., dan Isaac, J.H., 2007. Integrated Gayaberat and Seismik Interpetation in the Norman Range, Northwest Territories, Canada. Jurnal of Geophysics. Vol. 72, No. 5. P, B107-B112.

Nurdiyanto, B., Hartanto, E., Ngadmanto, D., Sunardi, B., dan Susilanto, P.,
2011. penentuan tingkat kekerasan batuan menggunakan metode seismik refraksi, jurnal meteorologi dan geofisika Vol, 12 No 3, 211 - 220.

Octonovrilya, Litanya. P, Putdja. I. P., 2009. Analisa Perbandingan Anomaly Gravitasi dengan persebaran intrusi air asin (Studi kasus Jakarta 20062007). Jurnal Meteorologi dan Geofisika Vol.10 No.1 : AMG

Reynolds, J.M.,1997. An Introduction to Applied and Environmental Geophysics, Chichester. John Wiley dan sons.

Sarkowi, M., 2008. Karakteristik Gradien Gayaberat Untuk Interpretasi Anomali Gayaberat Mikro Antar Waktu. Seminar Hasil Penelitian dan Pengabdian kepada Masyarakat. Unila

Susilawati. 2005. Pemodelan metode Gayaberat. Departement Fisika FMIPA UI

Supriyanto. 2007. Analisis Data Geofisika: Memahami teori Inversi. Department Fisika FMIPA UI: Depok. 


\section{LAMPIRAN}

Tabel 1. Operator Elkins filter SVD (Elkins, 1951)

\begin{tabular}{|rrrrr|}
\hline \multicolumn{5}{|c|}{ Operator Filter SVD menurut Elkins (1951) } \\
\hline 0.0000 & -0.0833 & 0.0000 & -0.0833 & 0.0000 \\
-0.0833 & -0.0667 & -0.0334 & -0.0667 & -0.0833 \\
0.0000 & -0.0334 & 1.0667 & -0.0334 & 0.0000 \\
-0.0833 & -0.0667 & -0.0334 & -0.0667 & -0.0833 \\
0.0000 & -0.0833 & 0.0000 & -0.0833 & 0.0000 \\
\hline
\end{tabular}

Tabel 2. Lebar Jendela Moving Average

\begin{tabular}{|l|l|l|l|l|l|l|}
\hline NO & NAMA & K & $\boldsymbol{\lambda}$ & N & REG & RES \\
\hline 1 & LINE A-A' & 0.000258 & 24333 & 24.33 & 16027 & 2457 \\
\hline 2 & LINE B-B' & 0.000245 & 25667 & 25.67 & 12398 & 1630 \\
\hline 3 & LINE C-C' & 0.000233 & 27000 & 27.00 & 12624 & 2181 \\
\hline 4 & LINE D-D' & 0.000314 & 20000 & 20.00 & 13891 & 2526 \\
\hline 5 & LINE E-E' & 0.000322 & 19500 & 19.50 & 10308 & 2529 \\
\hline & AVERAGE & 0.000274 & 23300 & 23.30 & 13050 & 2265 \\
\hline
\end{tabular}

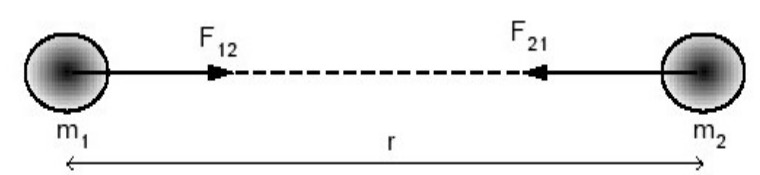

Gambar 1. Gaya Tarik menarik antara dua benda

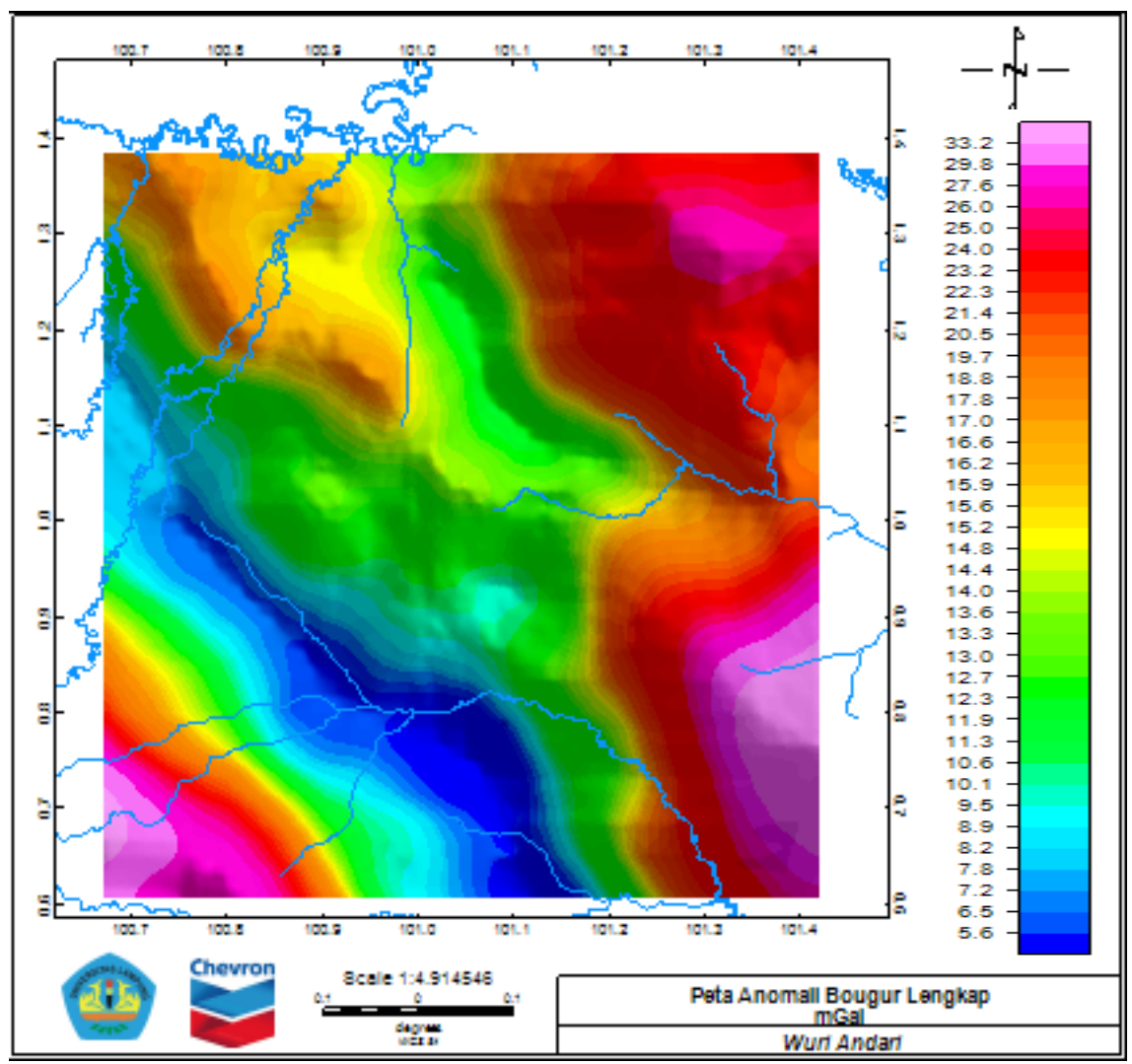

Gambar 2. Peta Anomali Bougeur 


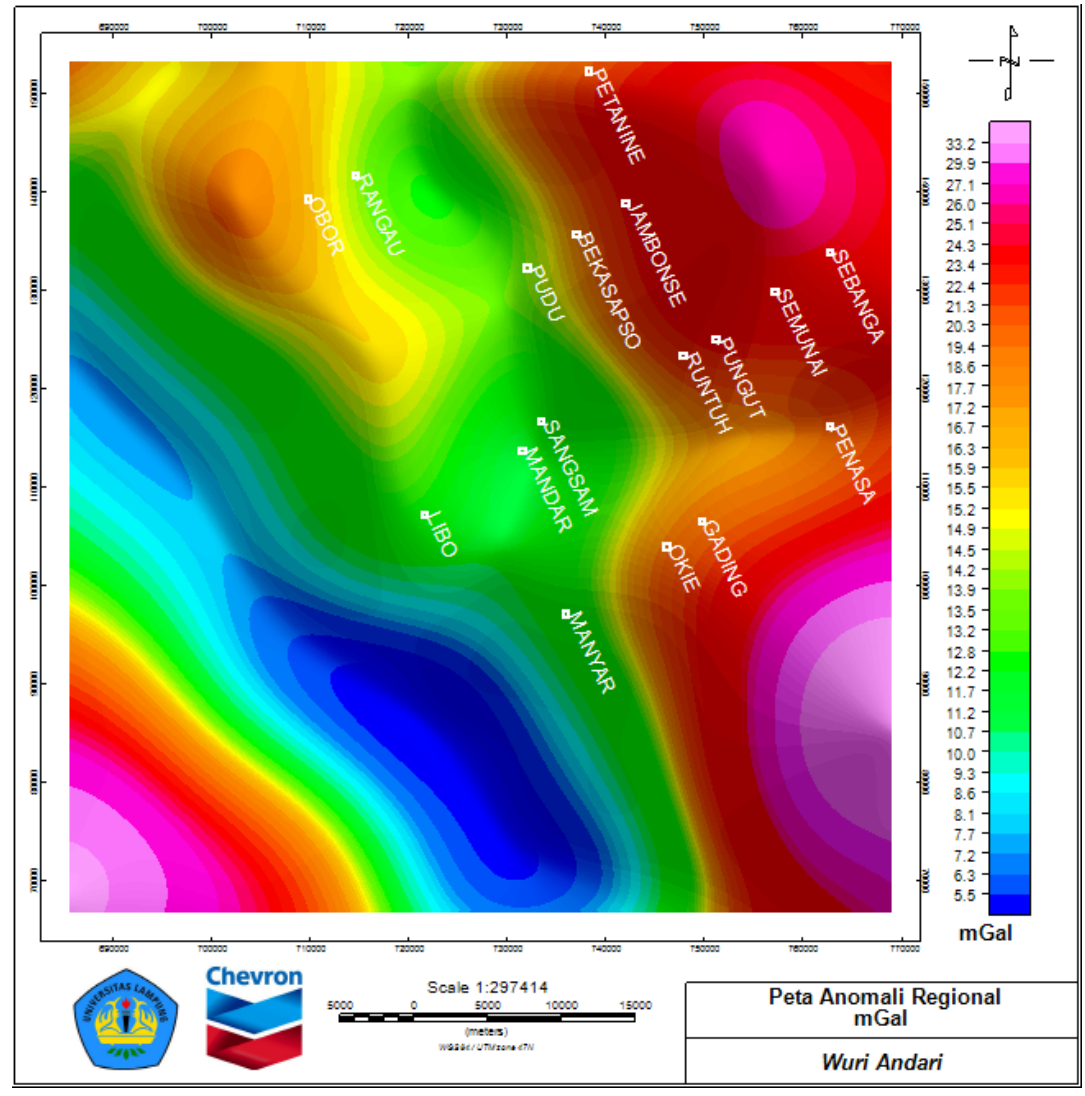

Gambar 3. Peta Anomali Regional Daerah Penelitian

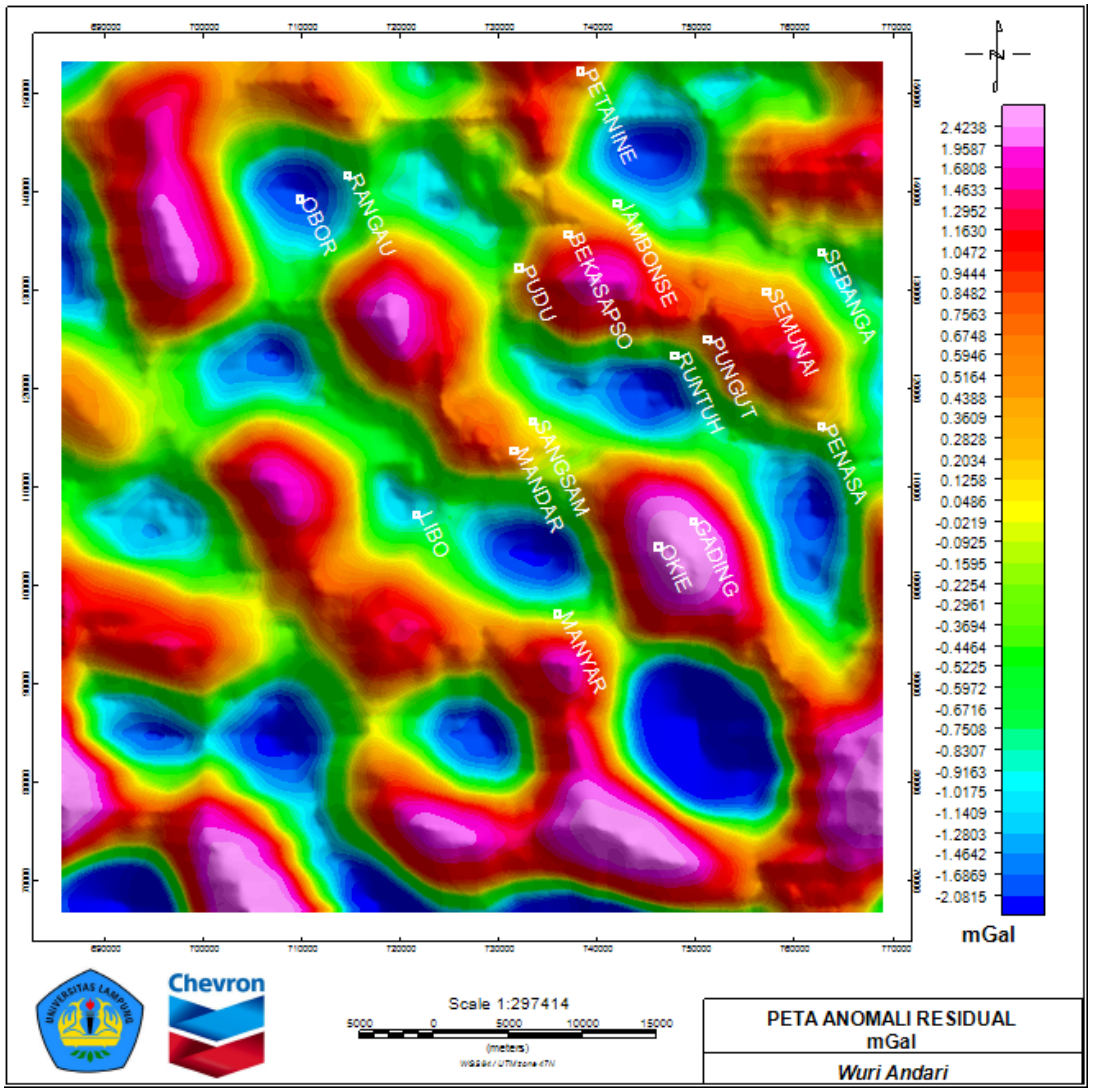

Gambar 4. Peta Anomali Residual Daerah Penelitian 


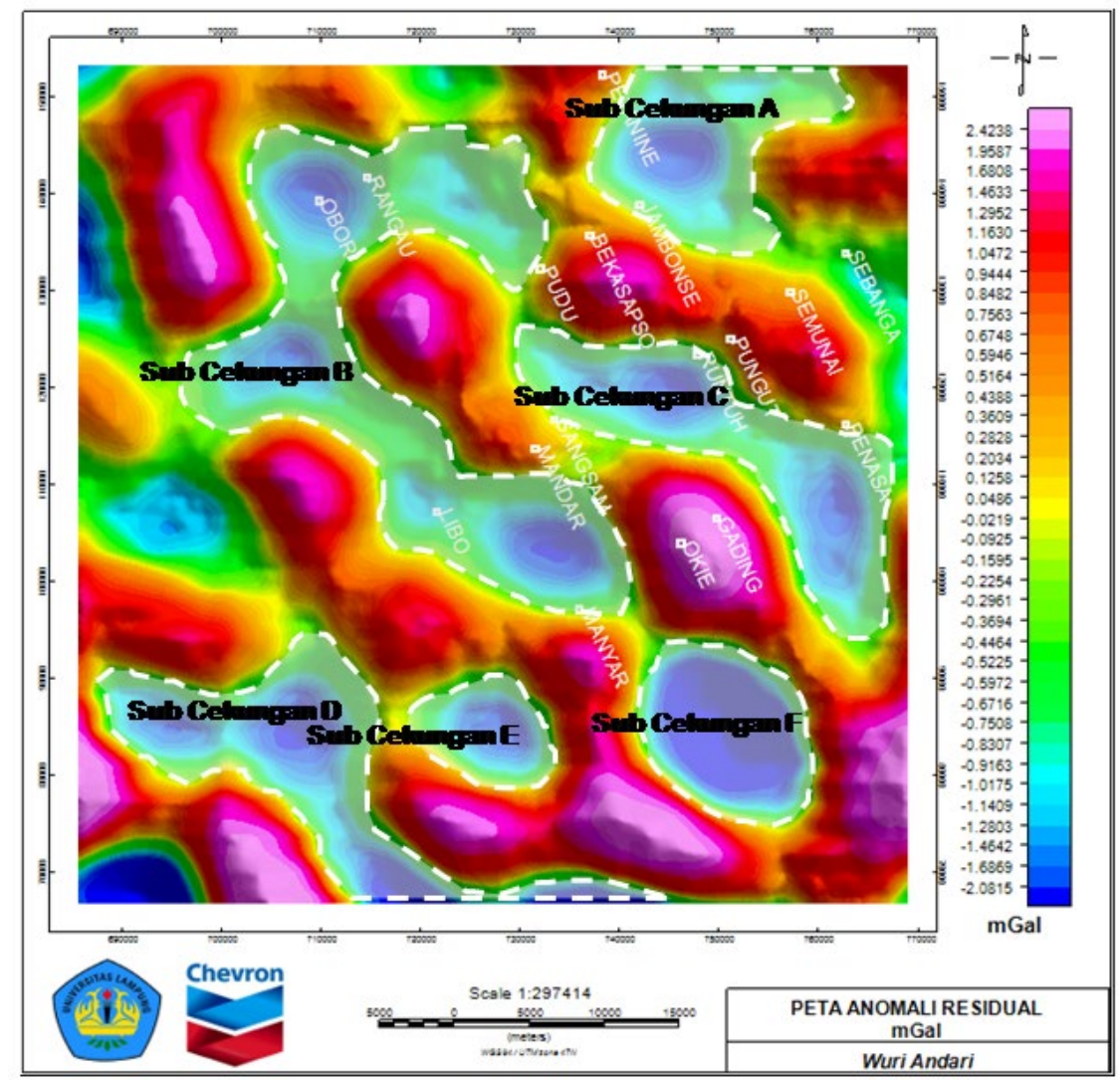

Gambar 5. Pola Sub-cekungan Daerah Penelitian

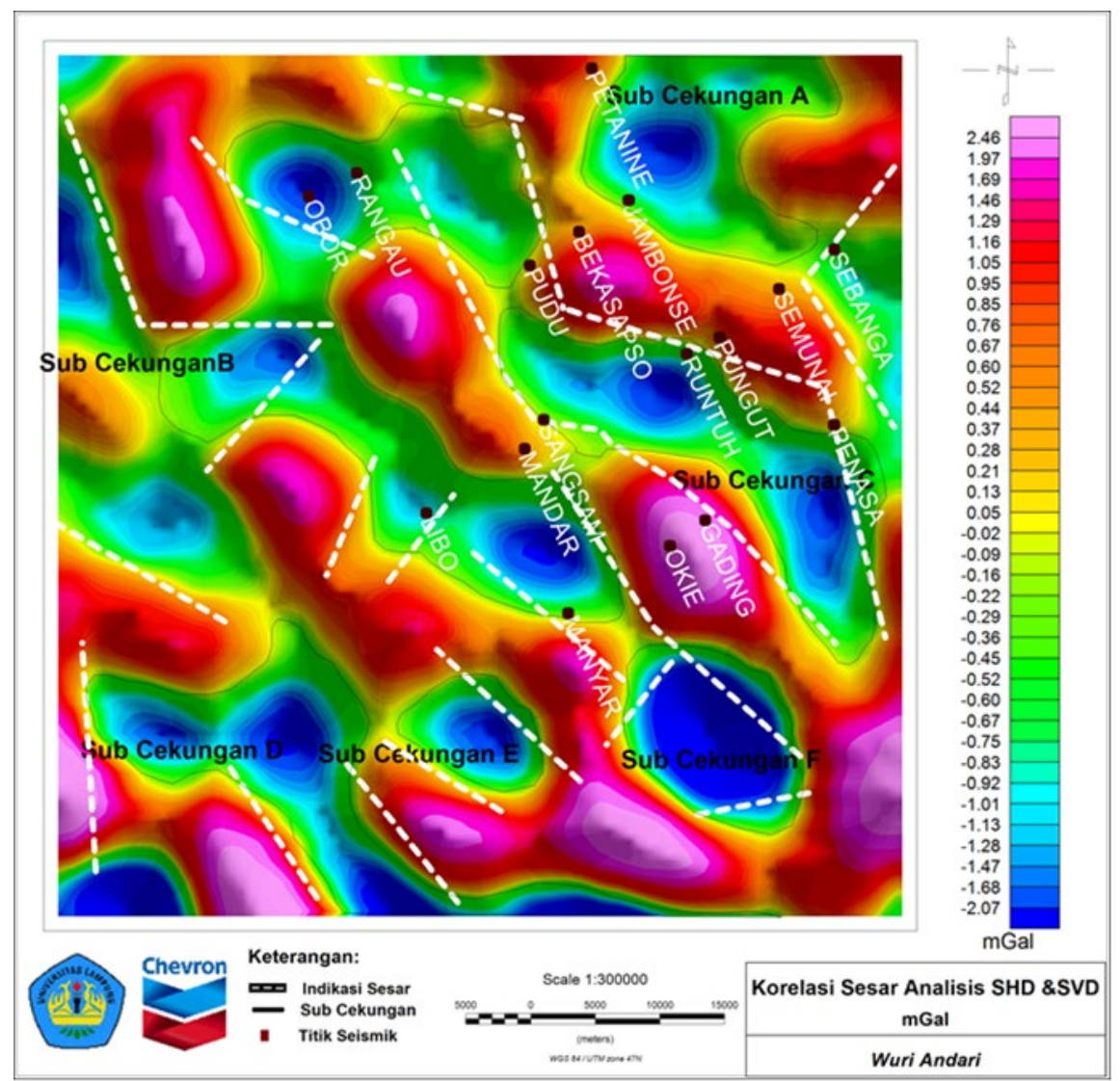

Gambar 6. Korelasi Sesar Analisis SHD dan SVD 


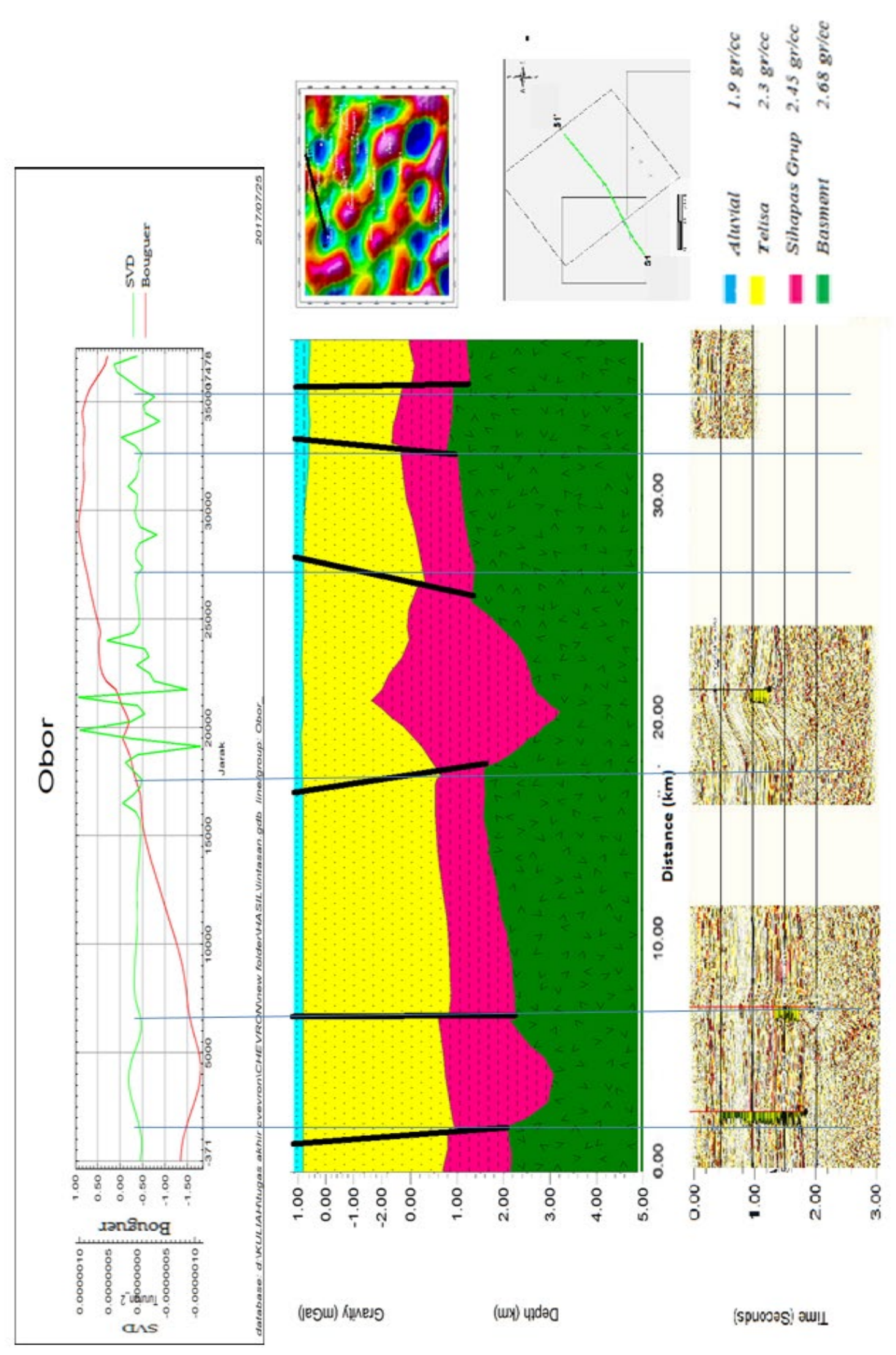


Jurnal Geofisika Eksplorasi Vol. 5/No. 1 Maret 2019: 60-74

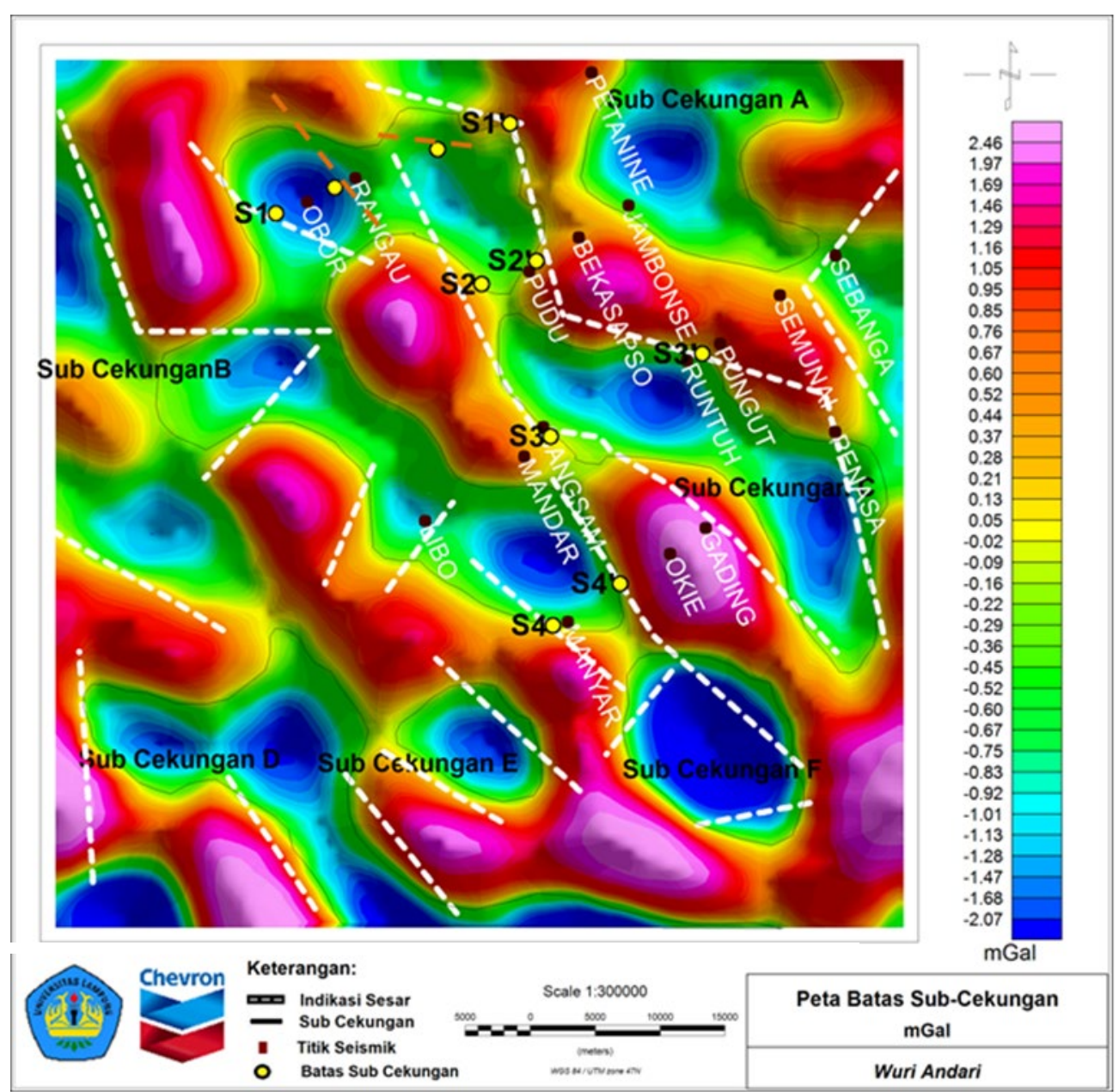

Gambar 8. Lokasi Batas Sub-cekungan Daerah Penelitian 